\title{
On the nature of musical scores and the rationale to prepare them: formulating directives
}

\author{
Marcus Alessi Bittencourt \\ Universidade Estadual de Maringá | Brazil
}

\begin{abstract}
Resumo: este artigo investiga a natureza das partituras musicais e o seu papel na comunicação entre compositor e intérprete. Amarrada pela narrativa da revisão de uma antiga partitura problemática, a investigação parte da ênfase dada por Derrida (1982) à ausência no fenômeno da escrita e do conceito de Leitor Modelo de Eco (1979), e sublinha a importância da improvisação no processo criativo e seu impacto no ato da escrita, introduzindo uma noção de hermenêutica a partir da distinção de Barthes (1977) entre Obra e Texto, do conceito de desapropriação poética de Bloom (1975) e da teoria dos atos de fala de Austin (1962), que é utilizada para trabalhar um modelo interpretativo tripartido. Segue-se uma discussão sobre a natureza puramente abstrata de uma composição e os obstáculos envolvidos na transcrição de performances. Durante o curso das discussões, a teoria investigada engendra doze diretrizes para a preparação eficaz de partituras musicais.
\end{abstract}

Palavras-chave: partituras, hermenêutica musical, escrita musical.

\begin{abstract}
: this paper investigates the nature of written musical scores and their role in the communication between composer and performer. Using as thread the narrative of the rewriting of a problematic earlier score, the investigation starts from Derrida's emphasis of absence in the phenomenon of writing (1982) and Eco's concept of model reader (1979), and stresses the importance of improvisation in the creative process and its impact in the act of writing, introducing a notion of hermeneutics from Barthes' distinction between Work and Text (1977), Bloom's concept of poetic misprision (1975), and Austin's theory of speech-acts (1962), which is used to create an interpretative tripartite model. There is then a discussion on the purely abstract nature of a composition and the pitfalls involved in the task of transcribing performances. During the course of the discussion, the rationale investigated engenders twelve directives for the effective preparation of musical scores.
\end{abstract}

Keywords: musical scores, music hermeneutics, music writing. 


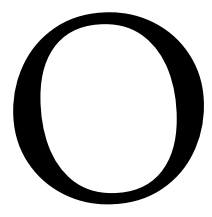

ne of the most challenging things for an apprentice composer to master is the ability to effectively write down his/her compositions. Speaking about myself (and from the perspective of a composer that also earns a living teaching exactly music composition), even though I have been composing and preparing scores for more than thirty years, I still marvel at how painful the process of starting the business of writing down a new composition can be, a feeling that only after a good deal of perseverance and patience during the course of the endeavor ends up evolving into a wonderful sense of real achievement when successful completion of the task has been attained. In this splendid (or perhaps not so splendid) age of ours of ubiquitous recording apparatuses, electronic music and fast circulation of recorded music and information, we may be tempted to think that written music is only a quaint remnant of olden days. Nonetheless, from a linguistic point of view (setting aside the obvious relevance and gain of being able to quickly communicate music to other musicians), to be able to formalize one's musical inventions through written means is of utter importance.

For the novice, first, there is the matter of aural training, the task of acquiring the ability to listen and then write, and to read and then perform. After that, there is the matter of gaining an understanding of what a musical score exactly represents, of what role it plays in the communicative process between a composer and a performer. After those two items are considered, then the final problem is to master the ability to prepare musical scores in the clearest and most effective way possible. In this paper, I intend to be dealing with the last two problems: I will try to shed some light into the meaning that musical scores have for the musicians who read and interpret them ${ }^{1}$, and I will try to derive from this rationale some directives on how a composer can best prepare a musical score for a new composition.

As a composer myself and a teacher of music composition, I have naturally spent a great deal of time and effort trying to master the art of writing music scores, both in practice and in theory. Nonetheless, it has been only recently, stimulated by a complicated compositional project of mine, that I felt that I could and should try to formalize my own theoretical thoughts about the preparation of musical scores. These present theoretical reflections were the by-product of my recent endeavor to

\footnotetext{
${ }^{1}$ Do notice that we will not be dealing here with understanding the multitude of potential meaning a musical work can have for its final destination listener, only with the meaning a musical score potentially has as a means of communication between composer and interpreter, in specific, and among musicians, in general.
} 
rewrite the score of an 18-year-old composition of mine, whose original score I deemed to have been insufficiently - if not inappropriately - written down.

\title{
1. Enter "Malédiction".
}

In 2001, I received a commission to write a piece for piano and live computer music, a kind of a concerto for piano and "unmanned electroacoustic ensemble", to be played at a Columbia Composers $^{2}$ recital at Columbia University in New York, having myself as soloist. It was actually my first experience with such type of composition (live instrument and electronics), and quite a lot of research had to be done at that time to develop that project. Since I had about two months to write the piece, program it in the computer and rehearse it, I decided that the best compositional approach would be a blend of fully-notated passages and structured-improvisation passages. In the first edition of the score of that work (which was dubbed "Malédiction"), this is how I described the piece for its reader-performer:

\begin{abstract}
This piece is not exactly an improvisation and it is not exactly fully written out, either. While playing the piano part, the pianist will also control the live electronics through a little keyboard attached to the lid of the piano. (...) The pianist will follow the instructions in the score and trigger the computer at the prescribed times. The computer will then take care of its own agenda and sound engineering. Each electroacoustic event is a set of live computergenerated improvisations on very strict pre-programmed patterns and structures. Each event will bear more or less the same elements, although they will never occur the same way twice. The pianist will interpret the score instructions according to his/her inner listening, but always reacting to the whole ensemble of sounds. (BITTENCOURT, 2001, cover instructions).
\end{abstract}

As intended, I did end up premiering the work in December 2001 at a recital at Columbia University’s Philosophy Hall in its New York Morningside Heights Campus, indeed with myself as soloist. I actually also had the opportunity to perform it live another three times, twice in 2004 at recitals at the University of Cincinnati (Ohio, USA) and at the College of William and Mary (Williamsburg, Virginia, USA), and then again in 2009 at a recital at the State University of Maringá

\footnotetext{
2"Columbia Composers" is a student-run organization supporting the creation and performance of new works by graduate students enrolled in Columbia University's Doctoral Composition Program, with the generous support of the Alice M. Ditson and the Fritz Reiner Funds (for more information, see https://music.columbia.edu/columbiacomposers).
} 
(Paraná, Brazil).

In terms of the actual musical composition itself, I have always been very satisfied with it: it is a single-movement, 18-minute work that makes use of a diverse collection of different and contrasting musical objects, all unified by one single strand of non-dodecaphonic serial DNA and contextualized in a formal structure that I consider to be one of the best I have ever designed for a large-form project. But its first musical score has been for me always problematic. I deemed it sufficiently fine only for myself to perform it. I never felt comfortable handing the piece to another pianist to do it. I just didn't have the confidence that the information contained in the pages of the score would lead the performer to produce the desired musical effects I intended, however competent and well-intentioned the performer may have been. During the years, I did receive some requests to perform the piece, and I promptly - and politely, I hope - turned them all down because I could not as a composer reconcile myself with the idea of accepting the possible outcome of another performer's reading of my score. The last of these requests happened at the beginning of last year and, since I was planning anyway a revival and a possible new recording of that work, I decided to go for a total rewrite of the piece, not a rewrite of the composition itself, but of its musical score. So, the question was: what was it in the score of the piece that mortified me? What was conceptually so utterly wrong about it that I should thoroughly set to neutralize and correct? Thus, the mission was set and stated: to produce a new score of Malédiction so that a reading of it by a competent musician would surely lead to the production of musical results that are acceptable and akin to the results I myself produced in my performances of it. Setting to accomplish that mission, the first action would be to uncover my theoretical misconceptions about the nature of musical scores and the very process of writing them down. The first clue to investigate: my symptomatic and clear aversion to handing over that piece's score to someone else.

\section{The natural realm of writing (in general) and music writing (in specific).}

The philosopher Jacques Derrida (1982) stresses that the phenomenon of writing is strongly marked by the long shadow of absence. First, the absence of the addressee: "one writes in order to communicate something to those who are absent"; and second, the absence of the sender, "the 
addressor, from the marks that he abandons, which are cut off from him and continue to produce effects beyond his presence and beyond the present actuality of his meaning, that is, beyond his life itself” (DERRIDA, 1982, p. 313). And he continues further:

A written sign is proffered in the absence of the addressee. (...) My "written communication" must, if you will, remain legible despite the absolute disappearance of every determined addressee in general for it to function as writing, that is, for it to be legible. It must be repeatable - iterable - in the absolute absence of the addressee or of the empirically determinable set of addressees. (...) A writing that was not structurally legible iterable - beyond the death of the addressee would not be writing. (DERRIDA, 1982, p. $315)$.

What holds for the addressee holds also, for the same reasons, for the sender or the producer. To write is to produce a mark that will constitute a kind of machine that is in turn productive, that my future disappearance in principle will not prevent from functioning and from yielding, and yielding itself to, reading and rewriting. (...) For the written to be the written, it must continue to "act" and to be legible even if what is called the author of the writing no longer answers for what he has written, for what he seems to have signed, whether he is provisionally absent, or if he is dead, or if in general he does not support, with his absolutely current and present intention or attention, the plenitude of his meaning, of that very thing which seems to be written "in his name". (DERRIDA, 1982, p. 316).

To write is to prepare a message-in-a-bottle, so to speak, with indeed all the perks that metaphor entails, including - and mainly - the enforced separation between sender and receiver. The composer Cornelius Cardew once expressed it quite nicely: "written compositions are fired off into the future; even if never performed, the writing remains as a point of reference" (CARDEW, 1971, p. xvii). If there is any chance of rescue (if not the rescuing of the very sender from the remote island, at least the rescuing of the sender's memory from oblivion), whoever finds that bottle needs to be able to somewhat decode its message. This will be possible either because the message is constructed by means of a conventional code commonly known by a society (and the receiver has to either belong to that society or at least have enough theoretical knowledge about it), or possible by means of the use of a "self-explainable" code that contains in itself the very key to its decoding. The fact that true writing needs to be structurally legible - iterable, as Derrida insists, "beyond the death of the addressee" - produces even curious by-products, as Cornelius Cardew (1971) points out: 
The great merit of a traditional musical notation, like the traditional speech notation i.e. writing, is that it enables people to say things that are beyond their own understanding. A 12-year-old can read Kant aloud; a gifted child can play late Beethoven. Obviously one can understand a notation without understanding everything that the notation is able to notate. To abandon notation is therefore a sacrifice; it deprives one of any system of formal guidelines leading you on into uncharted regions. (CARDEW, 1971, p. xix).

If the written message is to be understood as close as possible to the way the sender intended it - and I mean not simply to be able to decode the message, but to understand what the sender means by that message -, then it becomes clear that there must be some kind of supposition on the part of the sender of what type of receiver might be at the other end of his writing, and that it is quite natural that the sender will have to construct his writing based on that supposition. The writer and semiotician Umberto Eco (1979) wove this very theme into his notion of the Model Reader:

To organize a text, its author has to rely upon a series of codes that assign given contents to the expressions he uses. To make his text communicative, the author has to assume that the ensemble of codes he relies upon is the same as that shared by the possible reader (hereafter Model Reader) supposedly able to deal interpretatively with the expressions in the same way as the author deals generatively with them. (ECO, 1979, p. 7).

At the minimal level, every type of text explicitly selects a very general model of possible reader through the choice (i) of a specific linguistic code, (ii) of a certain literary style, and (iii) of specific specialization-indices (a text beginning with /According to the last developments of the TeSWeST .../immediately excludes any reader who does not know the technical jargon of text semiotics). (ECO, 1979, p. 7).

It is actually pertinent to point out here that Eco was at that time very much interested in evaluating theoretically what was happening on contemporary music compositions by Karlheinz Stockhausen and Luciano Berio that are indeed very similar in spirit to that Malédiction work of mine:

Nonetheless, it is obvious that works like those of Berio [Sequence, for solo flute] and Stockhausen [Klavierstück XI] are "open" in a far more tangible sense. In primitive terms we can say that they are quite literally "unfinished": the author seems to hand them on to the performer more or less like the components of a construction kit. He seems to be unconcerned about the manner of their eventual deployment. (ECO, 1989, p. 4).

From observing that type of musical repertoire, Umberto Eco posits the concept of an open work, a work that, whenever performed (or experienced, or read), "will never be quite the same on different 
occasions. Yet they will never be gratuitously different. They are to be seen as the actualization of a series of consequences whose premises are firmly rooted in the original data provided by the author" (ECO, 1989, p. 19). Eco explicitly stresses here the limits imposed by the author's rules on the possible interpretations of an open work:

However, in this type of operation, "openness" is far removed from meaning "indefiniteness" of communication, "infinite" possibilities of form, and complete freedom of reception. What in fact is made available is a range of rigidly preestablished and ordained interpretative solutions, and these never allow the reader to move outside the strict control of the author. (ECO, 1989, p. 6).

You cannot use the text as you want, but only as the text wants you to use it. An open text, however 'open' it be, cannot afford whatever interpretation. An open text outlines a 'closed' project of its Model Reader as a component of its structural strategy.

(ECO, 1979, p. 9).

From this, Eco had naturally to formulate the inverse notion, one for a supposedly closed work, and I say "supposedly" because it seems that, although the positing of such concept would indeed illuminate in some respect its antipode counterpart, we may be dealing here with a cryptid like the Loch Ness Monster:

We have seen that, pragmatically speaking, this situation [a perfectly well-formulated Model Reader] is a very abstract and optimal one. In the process of communication, a text is frequently interpreted against the background of codes different from those intended by the author. Some authors do not take into account such a possibility. They have in mind an average addressee referred to a given social context. Nobody can say what happens when the actual reader is different from the 'average' one. Those texts that obsessively aim at arousing a precise response on the part of more or less precise empirical readers (...) are in fact open to any possible 'aberrant' decoding. A text so immoderately 'open' to every possible interpretation will be called a closed one. (ECO, 1979, p. 8).

A little return to Malédiction is needed at this point. As I mentioned before, that piece was originally designed as a blend of written music and structured improvisation. When I say "structured", I stress here exactly the fact that in the score there is a certain number of rules to be followed by the performer in order to solve the improvisational sections of the piece. My approach to building that piece's original score was to give the performer exactly that very sort of "construction kit” idea posited by Umberto Eco and, in this respect, that piece surely and closely orbits his concept 
of the open work. As such, some closed sort of model reader has to be formulated for Malédiction in order to best prevent possible "aberrant decodings" of its score. Nonetheless, before we can begin to define such model reader, it will be necessary to investigate in more detail the individual nature of the roles played by the composer and the performer in the creation of a musical performance, especially one that involves some component of improvisation. If there is any amount of improvisation involved in a piece, then there is no question that there will be some partial transfer of authorship to the performer. How much of it will depend on how open the work is. From Eco we learn that the amount of this transfer of ownership will be somehow regulated by the rules stipulated by the authorcomposer. Before trying to understand this, we will have to take a closer look at what improvisation is.

\section{The somewhat long road towards the nature of improvisation.}

In his Liber de Arte Contrapuncti of 1477, Johannes Tinctoris used the expression "cantare super librum" for the practice of improvising a second melodic line against a written cantus firmus (which was read directly from a music book), the idea here being that the singer would strictly ground his invention on previously learned counterpoint rules (BENT, 1983, p. 372-373). Whenever a more dense and complex counterpoint was needed, or whenever one wanted to formalize in more strict terms a given polyphonic invention (and a more auspicious one, in the sense that only the best musical solutions were to be kept), one could resort to fully notating down the musical lines created. The result of this process was called by Tinctoris "res facta" (the "accomplished thing"). On a quick first glance, one can see here a connection between res facta versus super librum cantare and the concepts of written-down composition versus improvised composition, respectively (FERAND, 1957, p. $142)^{3}$.

When I was first writing down Malédiction, I did entertain that the act of reading its score would be somewhat similar to that "cantare super librum" practice of the Renaissance. Indeed, the first solution I actually intended to give to the problem of rewriting that score was to prepare two

\footnotetext{
${ }^{3}$ Actually, the full extent of the meaning of those two terms is subject to quite a bit of musicological dispute (for this, see FERAND, 1957; and BENT, 1983), but this more general version of their meaning will be sufficient for our purposes here.
} 
different ones for the piece: one to be performed "super librum" (and that score was to be indeed just its original first score, tout court), and a "res facta" score, one in which I would not only have my improvisational passages fully written down (based on my best improvised versions), but I would also turn the piece's electroacoustic part (which was fabricated live by the computer by the application of strict algorithmic rules) into a fixed-media version, evidently containing only the most auspicious runs of the computational algorithms. This solution bothered me for two reasons. First, the super librum score was obviously still destined "for my eyes only" and of course that didn't solve my original complaint that I couldn't give the piece to someone else to play. Second, the res facta score, which was to be probably destined for all "other performers", did remove all the improvisational aspects of the piece, both the pianist's and the computer's, and that initially just seemed to me to violate the very spirit of the piece: its open-work, construction-kit aspect. But at a second glance, I felt that working out more fully my own improvisational solutions did help to better reveal the nature of my musical intentions; so I realized I could be misjudging the subtlety and nature of the relationship between improvised and written-down music.

Investigating further the res facta and super librum concepts (as avatars of the pair written music versus improvisation), we see that they refer more to an opposition between composing in a nonlinear sort of time (one in which the composer can linger all he/she wants when thinking up a musical passage and can go back in the music to correct mistakes or redo bad choices) versus composing in real time (that is, instantaneously and without the possibility of taking back what one has already uttered $\left.{ }^{4}\right)$. The pianist and composer Frederic Rzewski explains this with a very nice anecdote:

In 1968, I ran into Steve Lacy [the experimental jazz saxophonist and composer] on the street in Rome. I took out my pocket tape recorder and asked him to describe in 15 seconds the difference between composition and improvisation. He answered: 'In 15 seconds, the difference between composition and improvisation is that in composition you have all the time you want to decide what you want to say in 15 seconds, while in improvisation you have 15 seconds'. His answer lasted exactly 15 seconds and is still the best formulation of the question I know. (RZEWSKI apud BAILEY, 1993, p. 140-141).

${ }^{4}$ As in "Honour thy error as a hidden intention" (ENO, Brian; SCHMIDT, Peter. Oblique Strategies. 1975). 
As a matter of fact, in many occasions I myself did hear the composer Willy Corrêa de Oliveira say that composing was to improvise in slow motion:

[Composing] is not an improvisation in real time but in slow motion. The composer has enough time to eliminate the weaknesses of the work, and this is what we demand from him. What we ask him is that he correct those weaknesses, for he has ample time to do that. In one word: the composer must be picky. An improvisation is performed in the context of a system of reference, and it is the fruit of an expertise on an instrument, associated to a musical background. (Willy Corrêa de Oliveira, apud ULBANERE, 2005, Annexes, p. 102, author's translation $)^{5}$

One can infer from both these last two statements that, under the same referential musical language, written compositions and live improvisations are made out of the same musical ingredients: "something" is to be said, and this something is anyway said according to the same "rules of speaking", no matter how one came about to saying it. So, we have it that writing and improvising music should be but two different approaches to the same process/act of composing.

As a corollary to this, we have it that improvisation - even if only performed mentally - is an integral, component part of the creative process involved in the composition of a written piece of music. I would even say that improvisation is actually imbricated to the compositional process to such an extent that it is just not possible at all to compose, either instantly or in nonlinear time, without the recourse of improvisation as a tool. I like explaining the way improvisation is used in the process of composing by making an analogy to the plot of the 2007 American science-fiction action thriller "Next": in that movie, a man has the power of somewhat seeing into the future, but with the twist that he can only see into the next two minutes of his own future. This ability allows him to investigate beforehand the outcomes of all the possible actions he might take in the present, and he then uses this knowledge (which miraculously seems to the outsider to have been acquired instantly) to select only the best and most fortunate course of action. When composing in nonlinear time, the author first tries out musical ideas during multiple sessions of improvisation, either mentally or at an

\footnotetext{
5In the original: "[Compor] não é um improviso em tempo real, mas em câmera lenta. O compositor tem tempo de eliminar as fragilidades do trabalho, e é isso que cobramos dele. O que pedimos é que ele corrija essas fragilidades, pois tem tempo hábil para isso. Em uma palavra: o compositor tem de ser crítico. Um improviso é feito dentro de um sistema de referência, e é fruto de uma destreza com um instrumento, aliada a uma experiência musical" (Willy Corrêa de Oliveira, apud ULBANERE, 2005, Anexos, p. 102).

${ }^{6}$ The film "Next" (2007) was directed by Lee Tamahori and it has Nicholas Cage starring in the leading role.
} 
instrument, and from these sessions follows a selection process whose purpose is to zoom in to the most well-formed and useful version of those musical ideas. It is only at this point of the creative process that an idea can be deemed 'ripe' for being committed to writing. A real-time version of this composition process (which necessarily has to be a somewhat simplified version of it, concocted diachronically and without the 'redo' option) would be what we usually refer to as extemporization, or the 'miracle' of live improvisation.

That corollary explains a lot about my reluctance to accept another person playing my piece. Deep down (alack, the vicissitudes of the unconscious...), I somewhat knew that the improvisatory aspects of the piece represented just an intermediate step in the creative process of the piece's composition. Several other further creative steps still had to be taken for turning those improvisational instructions into the final musical product I envisioned as an author. Since I am exactly the very author of the piece, in my own performances I could indeed, by extemporization, successfully overcome that gap between the sketched written signs and the well-formed version of the music intended to be played. It is clear why I could never delegate that task to another performer: it was not just a matter of simply accepting his/her interpretation of my score (the nature of which we will also discuss here later on), but I would have to be delegating to someone else the task of completing my sketches into a finalized piece. I would be sharing a parcel of authorship which I was not comfortable at all to give away and, as such, my score was not yet a finalized product, just a seed for one. My absence, as author, was not yet possible. Recalling Derrida, we find that my score was not quite yet writing, in that sense meant by him. Thus, we discover our first directive for effective score preparation: one should write in such a manner that one oneself can - and will desire to - be absolutely absent from the posterior activity of reading one's score. My supposed musical score was felt to be inappropriate precisely because it contained passages which, after all, just consisted of unfinished scribbles, and worse: scribbles that only I could successfully read.

A second directive can also be posited at this moment: before being up to the task of exercising the act of writing, one must decide exactly how far to go in enforcing one's own authorial vision, and then take the necessary steps to shape that idea all the way up to that point; an idea will be ready to be successfully written only when it has been acknowledged that it has reached its most adequate formulation possible. In his Klavierstück XI of 1956 (the piece mentioned here earlier in a quote by 
Umberto Eco), Stockhausen decided (and meant) to give the performer the permission to choose freely the playing order of 19 very short fragments of music he conveniently disposed over one single - and rather large - page, and he was indeed very happy with his decision of doing so. This very freedom and the multiplicity of possible musical results that ensued from it were an integral part of Stockhausen's musical design for that piece. This was not the case of my Malédiction piece, else I would be also happy to grant a similar freedom to the performer, which I clearly was not. In order to be able to really prepare a written score of that piece, I would have to effectively undergo the process of taking all the creative steps still necessary to finalize the musical objects I did envision but had only hurriedly sketched in my initial notation.

Writing down musical ideas can be a very slow, painful and exasperating experience. Not exactly because of its technical difficulty (for our discussion here, we are indeed assuming that the composer has already mastered the aural skills necessary for music transcription), but because the act of writing entails making choices, and this is hard, for choosing means favoring one formulation of an idea in detriment of all others that end up being jettisoned to our dismay. Choosing means being picky, as Willy Corrêa de Oliveira said, it means accepting only the most perfect solution and not resting until that has been found. And it also means knowing when to stop fiddling with an idea, accepting that it has reached a sufficiently satisfactory formulation. Karl Filtsch (1830-1845), a young pupil of Frédéric Chopin's, recorded on a letter from March 1842 a very touching testimony on the painful difficulties his teacher had when writing down his compositions:

\footnotetext{
The other day I heard Chopin improvise at George Sand's house. It is marvelous to hear Chopin compose in this way: his inspiration is so immediate and complete that he plays without hesitation as if it could not be otherwise. But when it comes to writing it down and recapturing the original thought in all its details, he spends days of nervous strain and almost terrible despair. (Karl Filtsch, apud HEDLEY et al, 1980:298).
}

I will return later on to investigate further this task of transcription, but at this point I would like to remark that the first scribbles of an idea are nonetheless very important written intermediate steps in the quest for the idea's final formulation, which usually only materializes after the patient layering of sketches upon sketches of it. And hence comes our third directive: one composes music by means of the combined effort of several trial runs of improvisation sessions, either at an instrument or mentally, either in real time or in a nonlinear time; thus, properly transcribing those improvisations is 
a common and very important part of the compositional creative process, one which should never be underestimated.

To complicate matters further, when a musical passage encounters its final written form, one is usually left with the feeling that something important ended up being lost after its translation as writing. The composer Ferruccio Busoni (1911) asserts that this loss is unavoidable and that the performer (the addressee of the text prepared by the addresser-composer) should be the person able to restore that back to us:

\begin{abstract}
Notation, the writing out of compositions, is primarily an ingenious expedient for catching an inspiration, with the purpose of exploiting it later. But notation is to improvisation as the portrait to the living model. It is for the interpreter to resolve the rigidity of the signs into the primitive emotion. (...) What the composer's inspiration necessarily loses through notation, his interpreter should restore by his own. (BUSONI, 1911, p. 15-16).
\end{abstract}

How is it that the performer is able to resolve that "rigidity of the signs"? When discussing Eco's open work concept, we did single out the necessity of a formulation of a specific model reader for one's text, a hypothetical reader that the writer supposes can, within an acceptable margin of error, handle the contents of the written message and understand what it means, even though supposedly mutilated by its own "written rigidity". The next matter at hand will surely have to be to investigate the mechanics behind the interpretation of texts.

\title{
4. Exeunt all. Enter Hermeneutics.
}

The evidence already presented here suggests that we will do better by casting off from our brains the notion that texts are to be understood merely by their "face value", by what is crudely represented by just its formative elements (the written symbols). Whatever a musical composition is (it is some sort of purely mental construction, but we haven't discussed this yet), its score is definitely not something like a photograph or an X-ray of it. A musical score is more like an architectural blueprint of the musical composition, a collection of graphemic indications which the composerauthor prepares in such a way that they can, by the interpretive powers of the right type of reader (our "model performer"), conjure a sufficiently appropriate image of that musical composition in the mind of that reader, which then goes on to play a version of that in the real world (a version of the 
music, not the actual written text markings!), and appropriately, that is, in a manner that would supposedly "please" the composer, even if only in an imaginary way. Thus, invoking the writer, semiotician and philosopher Roland Barthes, "to compose, at least by propensity, is to give to do, not to give to hear but to give to write" (BARTHES, 1977, p. 153). And so, we trespass into the domain of hermeneutics.

Starting from the usual widespread notion of hermeneutics as being "the art of understanding and of making oneself understood" (ZIMMERMANN, 2015, p. 2), I will here posit for us a little twisted version of that: hermeneutics is the art of understanding a text and of making oneself understood by means of preparing texts. To figure out what a 'text' is - which should definitely be our next step -, we will have to invoke again Roland Barthes (1977), which makes an important distinction between the 'work' and the 'text'. If the 'work' is simply the product itself prepared by the author (physically speaking), the 'text' is that work caught in the web of a vast network of multiple other texts. Barthes explains:

The difference is this: the work is a fragment of substance, occupying a part of the space of books (in a library for example), the Text is a methodological field. The opposition may recall (without at all reproducing term for term) Lacan's distinction between 'reality' and 'the real': the one is displayed, the other demonstrated; likewise, the work can be seen (in bookshops, in catalogues, in exam syllabuses), the text is a process of demonstration, speaks according to certain rules (or against certain rules); the work can be held in the hand, the text is held in language, only exists in the movement of a discourse (or rather, it is Text for the very reason that it knows itself as text); the Text is not the decomposition of the work, it is the work that is the imaginary tail of the Text; or again, the Text is experienced only in an activity of production. It follows that the Text cannot stop (for example on a library shelf); its constitutive movement is that of cutting across (in particular, it can cut across the work, several works).

(BARTHES, 1977, p. 156-157).

We know now that a text is not a line of words releasing a single 'theological' meaning (the 'message' of the Author-God) but a multi-dimensional space in which a variety of writings, none of them original, blend and clash. The text is a tissue of quotations drawn from the innumerable centres of culture.

(BARTHES, 1977, p. 146).

Thus is revealed the total existence of writing: a text is made of multiple writings, drawn from many cultures and entering into mutual relations of dialogue, parody, contestation, but there is one place where this multiplicity is focused and that place is the reader, not, as was hitherto said, the author. The reader is the space on which all the quotations that make up a writing are inscribed without any of them being lost; a text's unity lies not in its origin but in its destination. (BARTHES, 1977, p. 148). 
Here, it goes without saying that the figure of the supposed author is by necessity also a type of reader. And every author, because of being a reader, suffers the anxiety of having to cope with the weight of the whole canon of writings made by humanity. As the literary critic Harold Bloom (1975) would say - in his usual poetic and psychoanalytic vein -, "poetry is poems speaking to a poem, and is also that poem answering back with its own defensive discourse” (BLOOM, 1975, p. 276). We are here under the aegis of Bloom's theory of poetic misprision as a strategical defense mechanism for the self-survival of authors:

Poetry begins, always, when someone who is going to become a poet reads a poem. But I immediately add - when he begins to read a poem, for to see how fully he reads that poem we will have to see the poem that he himself will write as his reading. If we are talking about two strong poets, with a genuine difference between them, then the reading we are talking about is necessarily a mis-reading or, as I like to call it, a poetic misprision. (...) A reader understanding a poem is indeed understanding his own reading of that poem. If the reading is wholly a received one, then it will not produce other readings. An entire academy can convene to declare that reading the right one, but of course it will be wrong. It will also be weak. There are weak mis-readings and strong mis-readings, just as there are weak poems and strong poems, but there are no right readings, because reading a text is necessarily the reading of a whole system of texts, and meaning is always wandering around between texts. (BLOOM, 1975, p. 275).

If one asked a Text its name, the reply would be similar to "the words of the man possessed by demons (Mark 5:9): 'My name is Legion: for we are many'” (BARTHES, 1977, p. 160) - to what Harold Bloom would most likely further add that those voices would be heard in the inquirer's own voice-over. And so, we have our fourth directive: a musical composition is always created as a response of an author to another composition that author [mis]read; as such, a composition always inhabits an intertextual universe, no matter if its author consciously desires it or not.

Roland Barthes leaves us still another clue for understanding the nature of this "writing-asreading" affair, stating that such writing would designate "exactly what linguists, referring to Oxford philosophy, call a performative, a rare verbal form (...) in which the enunciation has no other content (contains no other proposition) than the act by which it is uttered (...)" (BARTHES, 1977, p. 145146). Barthes is here speaking of the theory of speech-acts developed by the philosopher of language J. L. Austin in the mid-twentieth century.

J. L. Austin worked out the idea that, upon the utterance of certain types of sentences, three kinds of meaningful acts could be performed: the locutionary, illocutionary, and perlocutionary acts. 
The locutionary act would be simply "uttering a certain sentence with a certain sense and reference, which again is roughly equivalent to 'meaning' in the traditional sense" (AUSTIN, 1962, p. 108). Austin then remarks that there are some "utterances which have a certain (conventional) force" (AUSTIN, 1962, p. 108), and that those utterances cause what he called and illocutionary act, a "performance of an act in saying something as opposed to performance of an act of saying something” (AUSTIN, 1962, p. 99). Austin also posits the perlocutionary act, which is "what we bring about or achieve by saying something (...)" (AUSTIN, 1962, p. 108), explaining that "saying something will often, or even normally, produce certain consequential effects upon the feelings, thoughts, or actions of the audience, or of the speaker, or of other person: and it may be done with the design, intention, or purpose of producing them (...)” (AUSTIN, 1962, p. 101).

Extrapolating from Austin's speech-acts theory (actually hijacking it perhaps by some poetic misprision of my own), we can make the analogy that the plain contents of a musical score (which would be our actual "written utterance") represent the locutionary act performed by the composerauthor. This would be simply the meaning represented by the "face value" of the written markings contained in the score, to which we will refer as the locutionary statement of the musical score. But, as we've seen earlier, something important is left from the notation, and that something is the illocutionary act, that is, the meaning the composer actually intended to transmit by his/her locutionary act, which is the image of the purely mental entity that is the musical composition. We will refer to this as the illocutionary intention of the musical score. If the illocutionary intention is strong enough, the musician-reader will indeed understand the actual meaning intended by the author with his/her locutionary statement and react back accordingly, producing an appropriate performance of the composition, and that is the perlocutionary act of the whole written utterance process, to which we will here refer as the perlocutionary response of the musician-reader.

Returning to the original speech-acts theory, a perlocutionary act can only be as successful as the utterance's illocutionary effect is strong, that is, the issuance of an appropriate response from the audience depends on the degree of success in the transmission of the meaning one actually intended to convey with one's utterance. Of course, one may expect that things can eventually go haywire in respect to the reader correctly understanding the illocutionary act, as J. L. Austin explains: 
Unless a certain effect is achieved, the illocutionary act will not have been happily, successfully performed. (...) I cannot be said to have warned an audience unless it hears what I say and takes what I say in a certain sense. (...) So the performance of an illocutionary act involves the securing of uptake. (AUSTIN, 1962, p. 115-116).

Austin calls "infelicities" the doctrine of "the things that can be and go wrong on the occasion of such [performative] utterances” (AUSTIN, 1962: 14), and he argues that, for the illocutionary act to be successful, "there must exist an accepted conventional procedure having a certain conventional effect, that procedure to include the uttering of certain words by certain persons in certain circumstances (...)”(AUSTIN, 1962, p. 14).

Continuing my extrapolation from that theory, I will refer as illocutionary infelicity to the failure or deficiency on the part of the musician-reader in actually comprehending the illocutionary intention meant by the composer-author with his/her score - which of course will result in an inappropriate perlocutionary response. And we can pinpoint Austin's “conventional procedure”the ace-in-the-sleeve at the author's disposal to help preventing the occurrence of 'infelicities' - as being precisely the selection by the composer of a model performer (which is, naturally, Eco's model reader). In other words, the composer tries to prevent illocutionary infelicities by assuming that his/her score will be read only by a performer potentially able to operate inside the intertextual web inhabited by that score (because it is a Text, in the sense meant by Barthes). And so comes our fifth directive: the model reader for a musical composition is decided precisely at that moment in which its composer embarked on the act of composing as a response to a [mis]reading of another work; if this is true, then the author of a composition always also suits the prototype for its model reader, which is a person who can properly navigate and operate inside the intertextual universe inhabited by the composition.

To further exemplify this adaptation of J. L. Austin's theory, I would like to take the following opening line from Frédéric Chopin’s Mazurka Op. $17 \mathrm{n}^{\circ} 4$ (1834), as seen in figure 1: 
FIGURE 1 - Introductory phrase (ms. 1-4) from Frédéric Chopin’s Mazurka Op. 17 nº 4.

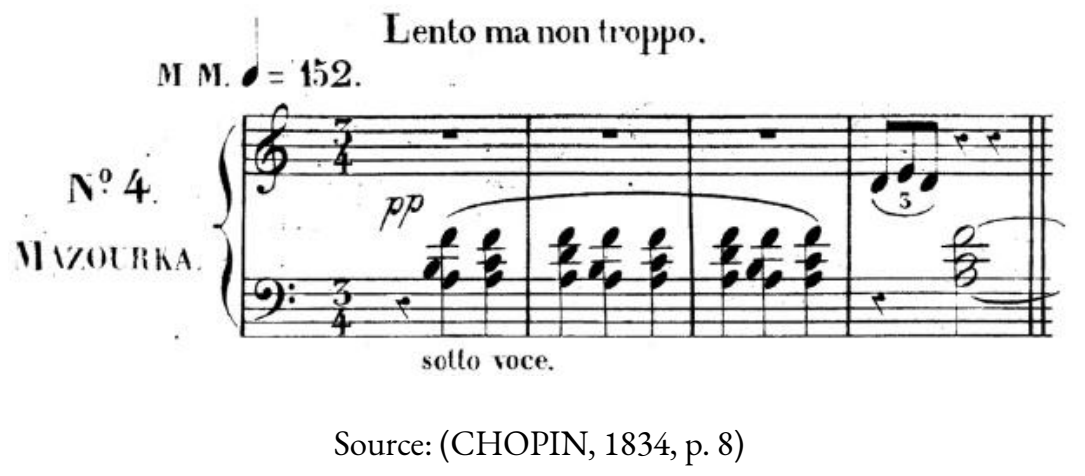

In the excerpt of figure 1 , the very collection of its written markings - which indicate graphically (and in quite plain terms) the features of that musical phrase in terms of specified durations, pitches, dynamics, character and articulation - represents the locutionary statement of that score fragment. I say here "in quite plain terms" because no musician worthy of that name would dare to play that phrase exactly as it is codified in symbols, like, for example, playing the indicated durations with perfect mathematical precision, playing the dynamics all evened out under the same pianissimo low intensity in decibels. If the pianist is compatible with the model-performer envisioned for that text, that is, if the pianist, aside from being literate in the sense of being able to decode the musical graphemic symbols used in the markings, knows the place that mazurka occupies in Chopin's repertoire and knows how it relates and connects, as a text, to that author's compositional output, to the whole canon of Western music, and to the historical performance practice of Romantic 19thcentury piano music, then there will be a certain illocutionary effect involved in reading that notation, and the pianist will have an understanding of what was meant by it, that is, its illocutionary intention (which most definitely transcends the notation's face-value locutionary statement), and he/she will respond by playing his/her version of that understanding as a perlocutionary response. As a matter of fact, if you (and I mean you, the reader of this very paper) are yourself compatible with the model performer for that score, then you would have already known exactly what I am talking about at the moment you first laid your eyes on those four bars of figure 1. If you have not, at this point, understood in what capacity the playing of the pianist has to transcend the mere notation contained in that example (and I most sincerely apologize in advance for the presumptuousness of this next statement of mine), then you yourself are not compatible with the model-reader for that text, and it is most certain that an infelicity, in J. L. Austin's sense, has just happened. Quod erat demonstrandum. 


\section{The forest of the purely abstract nature of a musical composition.}

I have already hinted at the idea that a musical composition has a "purely mental" nature, but we have not pursued this yet in detail. What, then, is a musical composition? We have already determined that it is not the actual musical score of a piece, for the score itself is merely a locutionary statement. It is only after a reader succeeds in grasping the score's illocutionary intention that the composition gets conjured in the reader's imagination and, as such, the composition should reside more in that imagination than in the score itself. The next question would be to know if a live performance or a recording of a musical piece, that is, a perlocutionary response of a performer, is equivalent to the musical composition. This is a question that has haunted, for example, quite a few ethnomusicologists when they try to study folk repertoire by means of analyses of performances. Bruno Nettl (1974, p. 7-8), for example, brings to our attention studies which show that it is not uncommon for improvising folk musicians to regard performances which on the surface sound rather dissimilar as being essentially one and the very same composition:

An example of this attitude can be found in the first reaction of a Persian musician who was asked to comment on the fact that two of his performances of the same dastgab were rather different: he denied that there was a difference. When confronted with the concrete evidence of the recordings, he admitted the existence of the differences, but not their significance, and implied that the essence of what he performed in a dastgab is always the same. His statements show that in Persian music it is possible to distinguish between what is essential and what is not; the former remains constant and is learned, while the latter is simply a result of the performer's mood of the moment. (NETTL, 1974, p. 8).

This account suggests that the correlation between what musicians think they are accomplishing and what they actually end up playing is not of an easy, straightforward type, being quite ambiguous and complex at times. Nonetheless, there are indeed recurring elements in a musician's renditions of a same piece, and the assumption is that those elements are the 'essential' features of the composition, essential in the sense that players will try to never leave them out of their executions. On the other hand, the noted differences in the renditions are deemed to be irrelevant precisely because such differences are not considered to be part of the music composition design, and therefore their presence in the playing does not hinder the unfurling of the composition itself, as composer and ethnomusicologist Constantin Brăiloiu (1949) remarks: 
In the absence of any irrefutable counterevidence, we must accept that we can only collect variants, and that an ideal archetype is latent in the minds of the singers, who provide us with ephemeral incarnations of it. We have to discover the essential properties of this archetype, which would not be what it is if the musicians could disguise all of its elements simultaneously. We must therefore assume that its basic structure cannot be altered by improvisation, which can only proceed freely insofar as it does not affect any of the features which make the abstract model recognisable. Comparison of variations will automatically bring out which parts of the melody are inalterable and which are ductile. (BRĂILOIU, 1949, p. 319-320 apud AROM, 1991, p. 141).

It is here clear that a performance of a piece of music, either live or recorded, also cannot be equated to the actual composition itself. One can then imagine the complications that can arise in the process of preparing a written transcription of a specific piece of music either from recordings or from live performances. Should the locutionary statement which is the score one is attempting to transcribe depict only the essential, recurring elements of the composition? If all one has of a piece are its performances, how does one distinguish if a heard element is an essential or a non-essential trait of the composition? The ethnomusicologist and social anthropologist John Blacking (1959) gives the following report on the problem of transcribing the music of the Venda people of South Africa:

Unless we are specifically studying interpretation, we want to know what a musician sets out to do each time he plays a certain piece of music, not exactly what he did on one particular occasion. If we were studying, say, a Chopin Mazurka from the evidence of performances, as we study an item of folk music, we would have to transcribe several different pianists' interpretations before arriving at a transcription which resembled Chopin's score. Only then would we be in a position to understand the structure of the music. The actual performance of the folk musician is really equivalent to the composer's act of writing down the music on paper, so that the music 'to be performed' has already been 'in existence' in the mind of the composer (...). (BLACKING, 1959, p. 15).

What we discover is that abstract ideas always pay a certain toll to be borne into the real world. As such, they can never manifest themselves into this world in any form other than a translation. Thus, we will always be dealing in the transcription process with two partially conflicting - but strongly correlated - entities: the inferred mental construct versus its actual manifestation in the real world. I will try to elucidate the source of that correlation extrapolating, mutatis mutandi, from the following comments by the linguist Roman Jakobson (1987) on the operation of metrical laws in poetry: 
Far from being an abstract, theoretical scheme, meter - or in more explicit terms, verse design - underlies the structure of any single line - or, in logical terminology, any single verse instance. Design and instance are correlative concepts. The verse design determines the invariant features of the verse instances and sets up the limits of variations. (JAKOBSON, 1987, p. 78).

Taking "verse instance" for a performance in the real world of a particular musical idea, we see that the instance can only be as pliant as its 'design' allows it to be (taking "verse design" for the abstract mental version of that musical idea). For a transcriptionist to actually be able to correctly identify the “verse design" implied by a "verse instance", he/she must - once again - necessarily be operating from within the same intertextual network of the repertoire being transcribed. Here we arrive at our sixth directive: fitting the model-reader profile, a proper transcriptionist will be the one who succeeds at recognizing the illocutionary intention that motivated the perlocutionary response which is the performance (or mental improvisation) being transcribed, and then goes on to operate the miracle of figuring out the most appropriate written locutionary statement that would be able to produce again such illocutionary effect in the mind of another reader suiting the same model reader prototype, eliciting anew the perlocutionary response of yet another proper performance.

Back to our former track, the nail-in-the-coffin to finish once and for all our illusions of a recording or live performance actually equating to a musical composition will come from this most radical stretch of the compositional act: the Musique Concrète, a type of music which exists solely as a studio-manufactured recording. The composer Pierre Schaeffer, the pioneer and arguably the most important theorist of that type of music, also noticed the abstract thought aspect involved in that and any - type of music making, and tried to explain this with his concepts of Thème et Version. Schaeffer (2017) considered that musical activity is like a stream that flows from the mind of the musician into the real world. The mind of the musician is the court inhabited by the 'Theme':

If he [the composer] listens, it is upstream of his musical activity; he sings in sol-fa in his head, plays in his mind and, if he is a very good musician, reads a score mentally, without any help from instruments; he composes in the same way. He does not hear; he reads - he 'prehears'. (SCHAEFFER, 2017, p. 60).

Do notice in that statement the expression "he reads": Schaeffer's thème is, of course, the abstract entity which is a musical composition: a complex blend of illocutionary intentions deduced from 
intertextual contexts and practices. Downstream that path, there is the real world, the place where the sounds are effectively heard and which is the court inhabited by the 'Version':

The sound engineer [that is, our performer], in contrast, makes it his duty to listen downstream from the sound phenomenon. What he is continually comparing, from his own listening, is the sound image provided by the electroacoustic system and the original sound phenomenon [the Thème], which he is endeavoring to reconstitute (...).

(SCHAEFFER, 2017, p. 60).

Schaeffer's version is then only a translation of the thème into the real world of sounds, that is, only a sort of avatar of the idea of the thème, not the theme itself. A Musique Concrète recording is in the end also just the perlocutionary response of a performer-composer who composed at the studio using the same improvisation-in-slow-motion creative technique described earlier.

And it is in this sense that I say that a musical composition is a "purely abstract construction", for it can't exist in the real world. Nonetheless, it always controls and determines its double in the real world, the performance, and, because of this, its performance is indeed capable of successfully impersonating a reflection of it. As for the musical score, it is also doubtlessly conditioned by the abstract model which it intends to imply. Even though its locutionary statement can be at times extremely precise in what it indicates in written symbols, it always needs to be intertextually read for a felicitous illocution and, in this respect, it also impersonates only a reflection of the abstract idea. Thus, the musical composition shows itself to be exactly that which Roland Barthes posits as being a 'Text', which can only be “experienced in an activity of production”, like Lacan's 'Real', never capable of being directly shown, only demonstrated by means of its real-world activities of reflection (BARTHES, 1977, p. 157). Hence our seventh directive: do understand that a musical composition is a purely abstract phenomenon; its written score and its performances are, each in its own way, only translated reflections of it.

From all this, we can generalize three crucial points. First, the musical score necessarily carries only essential traits of the composition, because its mission is to symbolically point at the "verse design”. However, it carries only an aliquot of those essential features, and the remaining ones have always to be inferred by the illocutionary part of the reading process. Second, the performance is always and only a somewhat distorted imitation of the composition, it is always a "verse instance" of it. Its likeness to the composition is due to its success in carrying and respecting a sufficient number 
of the design's essential traits. Its degree of distortion is due to the inevitable mingling of the essential elements with nonessential ones. Third, proper demonstration of the composition demands an active reading participation from all persons involved in the communicative process. Because of this, everyone involved in it has to be competent with the system of reference used, that is, the musical language being operated, and all must be immersed in the stylistic and referential intertextual universe inhabited by the composition.

\section{Re-enter "Malédiction".}

And so, we return to my original enterprise of recasting the score of Malédiction, a task I can now recount under the perspective of the rationale just discussed. Having realized that a good portion of that piece's music was not really improvisational at all as I first thought (which would make that initial solution of "super librum" and "res facta" scores a quite preposterous one), the first step in that rewriting process had inevitably to be to effect a revision of those musical ideas that had in the original score been shortsightedly sketched in the form of improvisational directions. The ultimate goal was to be absolutely faithful to the very specific way in which I used to solve those improvisational parts in my playing. The challenge to be met was to figure out how far I really wanted and needed the boundaries of my own authorial vision to go and use that limit to establish definitive final formulations for those sections of the piece. Luckily, I had recordings of my own successful performances of it to rely upon for this formalization task. I had also made in 2005 a studio recording of it, one in which I had explicitly selected and spliced in only my most favorite studio renditions of that score. This recording served as the basis for a meticulous work of transcription.

We have already discussed the high complexity of the task of transcribing a score from a performance, and to continue further we'll once again invoke Bruno Nettl:

Assuming that no human transcriber could reproduce all of the acoustical phenomena of a musical utterance, he should reproduce those which are essential, and deciding this is probably the most agonizing part of transcription. Electronic devices which transcribe probably cannot be made selective in this way. They record everything regardless of its importance, and selection of the essentials must be made later by the scholar.

(NETTL, 1964, p. 102-103). 
The goal in the transcription of a performance is not, as one may first imagine, to obsessively and accurately notate every single detail that was played. Recalling our sixth directive, here we must really work under the assumption that a musical score is only a locutionary statement of the musical composition it aims to evoke. The written markings of a score are thus, by their very nature, rather coarse and incomplete, and one has to accept and embrace that, which does not mean at all that musical notation can't or shouldn't be - and it often is - quite precise at times. However, one should definitely be on guard against those mentioned obsessive impulses when doing a transcription, for those impulses will not necessarily produce in writing the expected high level of accuracy, as Zygmunt Estreicher - yet another ethnomusicologist struggling with the task of transcription - points out to us:

\footnotetext{
The musician-performer attempts to materialise a specific musical structure. His deviant intonations, the occasional interruptions in his production, etc., do not count for him. (...) With respect to the formal aim (res facienda), the actual execution (res facta) is always imperfect. (...) A musical transcription which makes allowance for the performer's inaccuracies (...) takes over all his imperfections and becomes inaccurate itself. (ESTREICHER, 1957, p. 91 apud AROM, 1991, p. 143).
}

A good solution for this dilemma is to perform the transcription work of a specific passage in several steps, using each new step to further purge the notation of the nonessential elements. As Bruno Nettl observes: "it should be possible to move from transcription of all musical phenomena perceived by the transcriber to another transcription which gives only the essentials” (NETTL, 1964, p. 104).

Another characteristic feature of musical writing we've already investigated is that it must be calibrated to purposefully bear a certain illocutionary intention, that can only be felicitously understood by one of the model-reader kind. This means what we will posit here as our eighth directive: the composer can indeed safely omit some details from the score if those are easily inferable from intertextual contexts by the expected reader. One example of this practice of the reader filling in the gaps of the score's notation has been observed by Pierre Aubry (1909) on his work on medieval manuscripts of motets and troubadour songs. Aubry says that, although some 13th-century manuscripts show no indication or notation of rhythm, rhythm was nonetheless a very important component of that music. But it was understood as an intrinsic, latent knowledge, whose 
interpretation was subject to performance laws that were second nature to the musicians of that time, hence the relative innocuousness of its omission from the written text (AUBRY, 1909, p. 190-199). We see here what will become our ninth directive: the more consensual and established the performance practice of a musical genre is, the more implicit and laconic its respective musical scores can be (because the locutionary statement in them already bears a strong illocutionary intention); and conversely: the less consensual and established the performance practice of a musical genre is, the more explicit and detailed its respective musical scores must be (because the locutionary statement in them has to be more precise to compensate for carrying a markedly weaker illocutionary intention). Furthermore, the illocutionary intention can't be fully taken out of the game, for if it were possible to pedantically put in written symbols absolutely every single detail of a composition, one would most certainly invite the Loch Ness Monster to the dinner table: this would mean the absurdity of completely 'closing' the text, an act that would either invite all sorts of 'aberrant' decodings or would make the text stale by the preclusion of the possibility of any other reading of it. Our tenth directive comes right from this: only stale or aberrant readings are possible of a score of a composition for which there is absolutely no tradition of performance practice at all, even the tiniest one, because the illocutionary effect of its writing would be null.

Now, when we are specifically dealing with transcribing contemporary music, which often includes experimental linguistic elucubrations that lead naturally to equally experimental and more arcane performance practices, one can imagine that figuring out and calibrating the proper level of relaxation in the precision and obsession of the writing can be an extremely complicated matter. In this case of contemporary music, how does one figure out the proper way to operate and navigate the intertextual web? Is there even an actual intertextual web in that case? In my doctoral dissertation at Columbia University (BITTENCOURT, 2003), I defined the music I was - and still am composing as an "Experimental Music":

What interests me the most in contemporary music is its attempt to exist outside the orbit of a Musical Language, marginal, sometimes pointing to some known Musical Language, sometimes delving into such an individualistic position that it becomes unintelligible except to itself (or even to itself, in some more unfortunate cases). Maybe the best term to describe what we are doing is "Experimental Music", precisely because of its marginal "linguistic" character, because of its "tabula-rasianist" aspirations. The experimental composer desires this "Tabula-Rasa" even though he knows this is unattainable, that history cannot be wiped out. This is a music that tries to speak no Musical Language but 
nonetheless can't help but to remain informed by all the languages past and present.

(BITTENCOURT, 2003, p. 10-11).

In fact, it becomes clear that not even the pursuit of a tabula-rasa can take a text out of the intertextuality web: on Harold Bloom's list of creative anxiety-defense mechanisms (called by him "revisionary ratios"), the desire for a tabula-rasa would most likely be a case of 'askesis', that is, “purgation and solipsism” (see BLOOM, 1973, p. 115) - and this already says it all. Specially in our current globalized world - despite any wishes a composer may have to the contrary - it is impossible for a musical text to do anything but to "remain informed by all the languages past and present" - to which I would further add "as well as by the whole canon of known texts" -, even if by the renunciative act of askesis (recall here our fourth directive).

Once again back to Malédiction, after a process of becoming aware of the exact intertextual space my piece inhabited (either by affirmation or by negation - of the solipsistic kind), I could at last envision a specific model-reader for the new score of Malédiction. My plan was to work under the assumption that the piece was to be interpreted only by pianists knowledgeable and competent at a specific type of well-known 20th-century piano repertoire - such as the one's by Messiaen, Ives, Ligeti, Stockhausen, Babbitt, Rzewski, for example - which operate in a linguistic vein akin to the one of my piece, and thus neighboringly inhabit, give or take, pretty much the same intertextual universe. This model-reader election naturally required the use of traditional Western music notation for the score, with all the extra add-ons, perks and complexities - especially rhythmical ones - which are a common staple to that type of repertoire. As such, I carefully calibrated the inventory of graphemic symbols used in my new score to suit that assumption of a model reader. In this sense, what I did was to make those exact three decisions needed for the selection of a model reader that Umberto Eco singled out: the choices "(i) of a specific linguistic code, (ii) of a certain literary style, and (iii) of specific specialization-indices" (ECO, 1979, p. 7). These choices aim at securing that only a specific type of reader will get encouraged to attempt decoding the score. And from this we can formulate our eleventh directive: everything that can be written using the most traditional writing procedures accepted by the model-reader collectivity must be so written; everything that can't be done in that way must be written either using procedures that are less common but still known to the modelreader circles, or, that being also impossible, using newly-created symbols; nonetheless, the use of new and 
more obscure linguistic codes always warrant the need to include in the score some appropriate prefatorial explanatory charts.

Now, to give an account of the magnitude of the transcribing effort that had to be done in the process of rewriting the score of Malédiction, the next four figures show excerpts from two of the aforementioned improvisational solo piano passages as they are presented in the original score of the piece (reproduced in figures 2 and 4), followed by those same passages in their fully-notated newlytranscribed version (shown in figures 3 and 5).

FIGURE 2 - Excerpt from an improvisational passage of the piano part of the original Malédiction score.

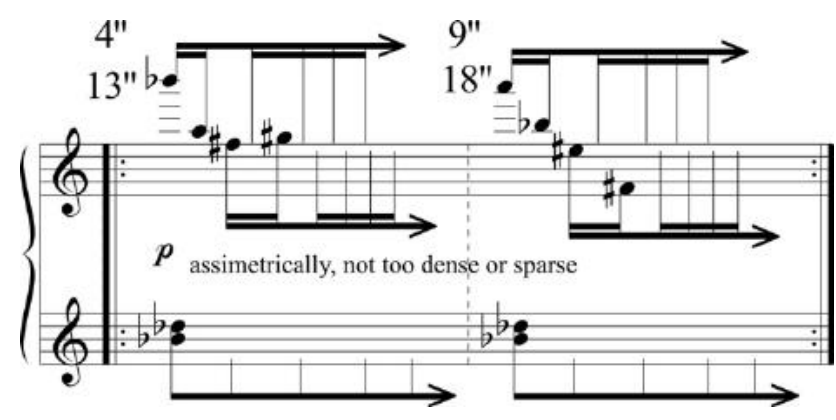

Source: BITTENCOURT (2001, p. 3)

FIGURE 3 - New fully-notated version of the music excerpted in figure 2.

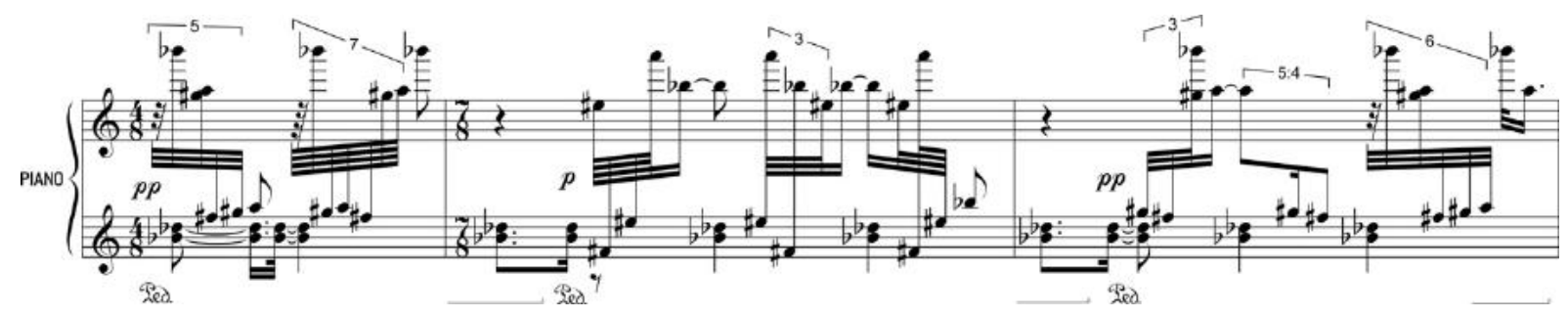

Source: BITTENCOURT (2020, p. 10) 
FIGURE 4 - Excerpt from a semi-improvisational passage in proportional rhythmical notation from the piano part of the original Malédiction score.

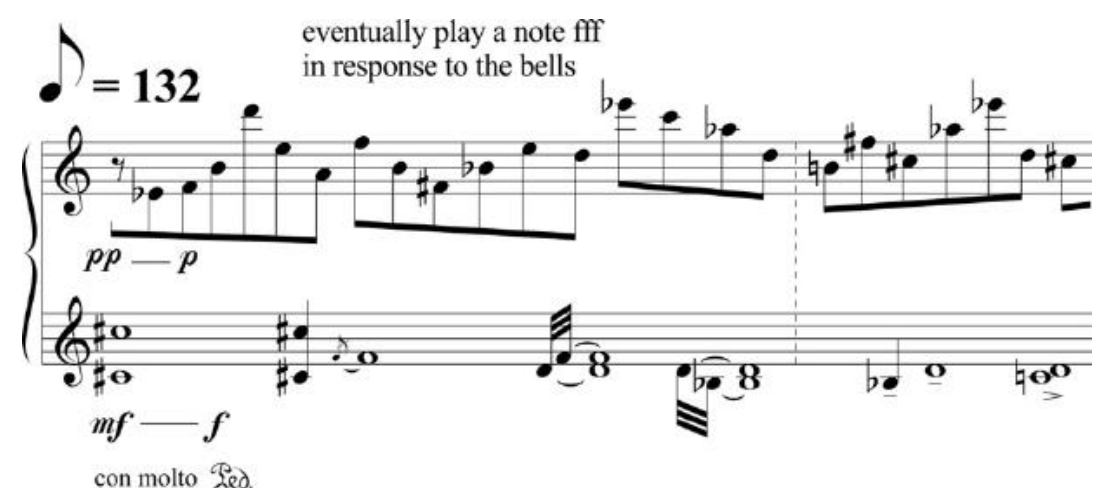

Source: (BITTENCOURT, 2001, p. 5)

FIGURE 5 - New fully-notated version of the music excerpted in figure 4.

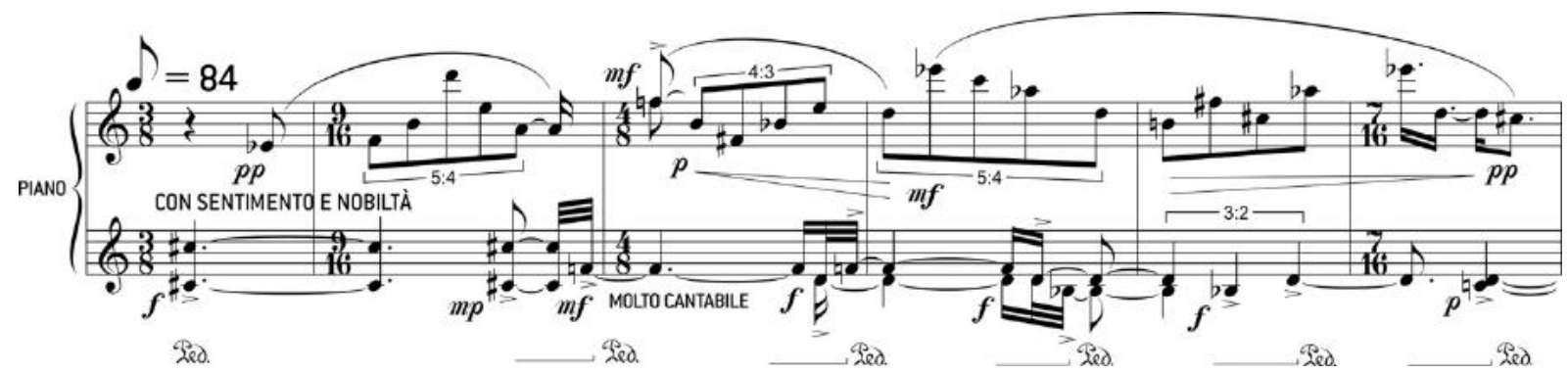

Source: (BITTENCOURT, 2020, p. 19)

Following this step of retranscribing the piano parts of the piece, the next mission was to address the problem of what to do with the written indications for the electroacoustic parts. The pianist wouldn't have to interpret those (in the sense we interpret texts), because computational algorithms integrally operate those parts live. Nonetheless, the presence in this type of score of some sort of notation for the electroacoustic parts is usually quite convenient not only to stir the imagination of the performer but to give important cues that facilitate his/her navigation of the piece. In my original score, those were just plain English-language indications - and very terse at that -, such as "wait for the introduction; after [a] gong, a massive crane noise starts" (BITTENCOURT, 2001, p. 1). 
This time, my intention was to hopefully do substantially better than that, and so I decided to actually notate in full those parts using a combination of extended traditional music notation extended in the sense that it includes some rather less common symbology, such as microtone accidentals and proportional rhythmic notation - with flowchart-style diagrams, so the pianist could understand what sort of musical objects and live algorithmic procedures the computer was supposed to be operating at a given point in time. The notations for the electronics were of course planned to be much simpler and more bare-bones than the solo piano parts, which were notated with the painful precision and completeness required of a piece of its repertoire genre. After all, there was no need to secure a correct interpretation of those electroacoustic parts from the reader-pianist, for the algorithms I myself programmed already guarantee that during the execution of the piece one will only listen to appropriate instances of the compositional designs. In a way, my programming work and all its deterministic rule-based behavior make myself the actual interpreter of these parts, my absence in the reading process being compensated for by the presence of an automaton made to mimic my own preferences. I also decided to use in the score a modified version of the excellent graphic symbols and notation methodology created by composer Lasse Thoresen for his adaptation of Pierre Schaeffer's typomorphology of the sound objects (THORESEN, 2007), which I find not only visually appealing but also very useful. Such use of new symbology naturally warranted the inclusion in the score of prefatorial explanatory charts. As an example of the resulting graphic designs utilized, figure 6 reproduces an excerpt from the electroacoustic part of the new score of Malédiction. 
FIGURE 6 - Example of notation for the electroacoustic part in the new score of Malédiction.

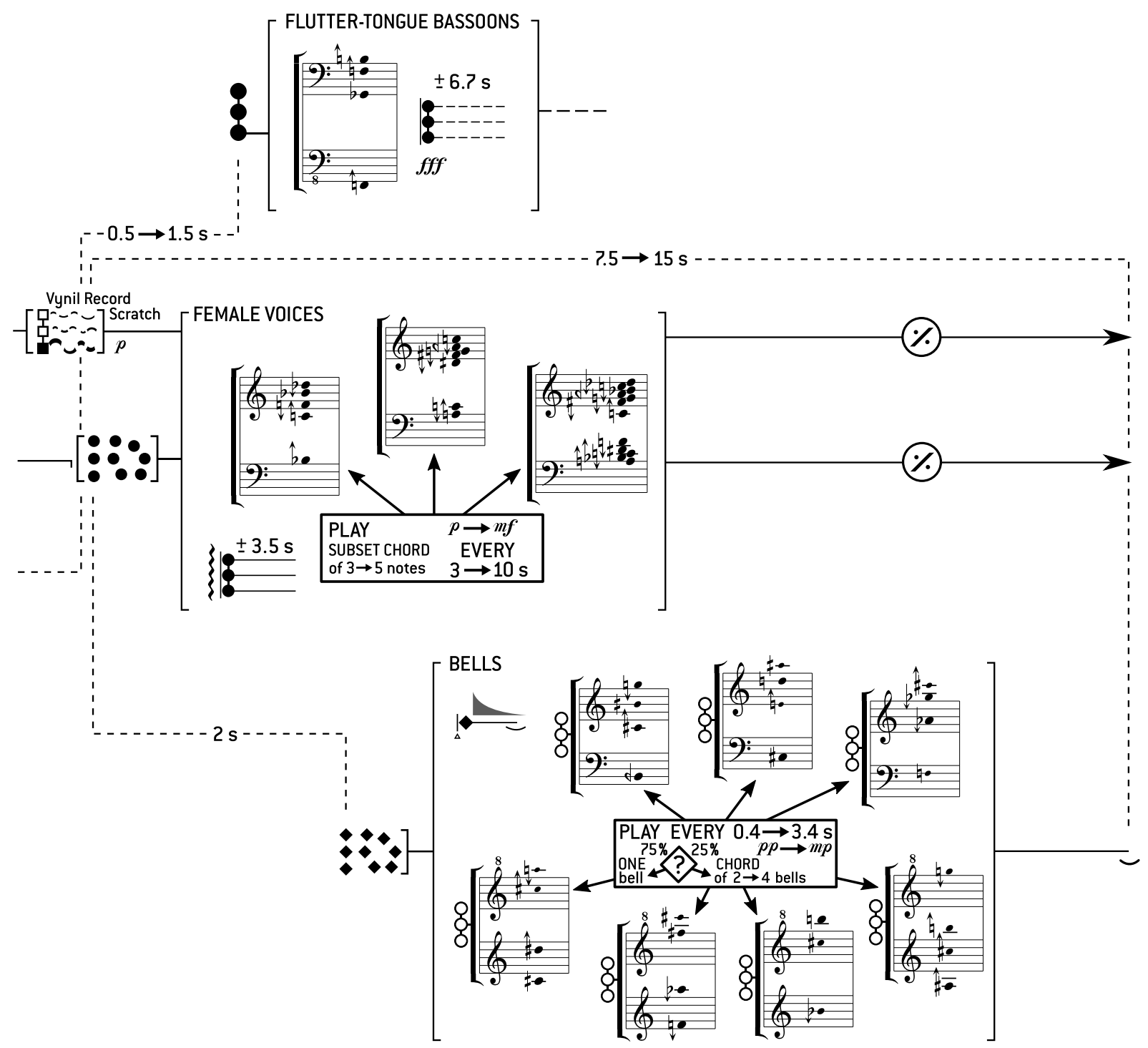

Source: (BITTENCOURT, 2020, p. 2) 
The final step in finalizing my new score was, of course, to combine together all those graphic elements in a full-score format. For that, I chose again to draw upon Lasse Thoresen's work (2007), combined with the traditional 20th-century-style Western music notation. The rather unorthodox format for the score required its typesetting to be accomplished by the joint effort of one ubiquitous commercial software (Finale ${ }^{7}$ ) with a couple of custom-made algorithmic postscript notation applications programmed by myself. The final assemblage of the graphical blocks was done in a freesoftware vector graphics editor (Inkscape $\left.{ }^{8}\right)$.

The last two figures show a more full-fledged example of the revamping process undergone by Malédiction's score. Figure 8, which reproduces the complete page 15 of the new score, rebuilds entirely the first half of the original corresponding laconic notation reproduced in figure 7.

FIGURE 7 - Original laconic notation for the music excerpted in figure 8.

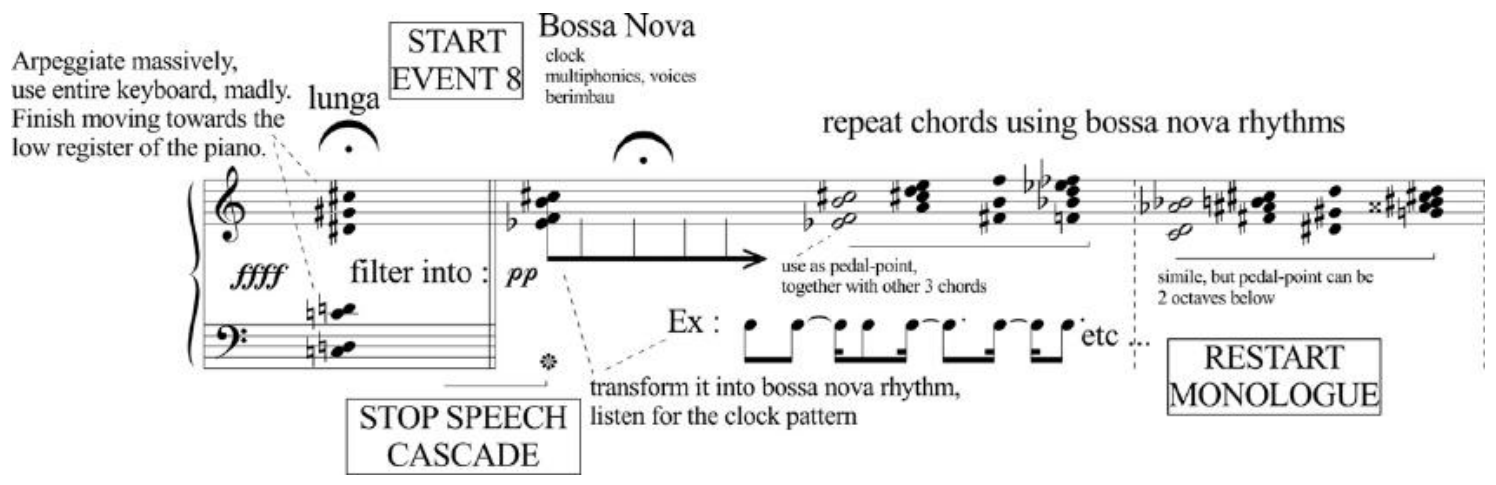

Source: (BITTENCOURT, 2001, p. 4) 
FIGURE 8 - Page 15 from the new score of Malédiction, showing the first half of the music excerpted in figure 7.

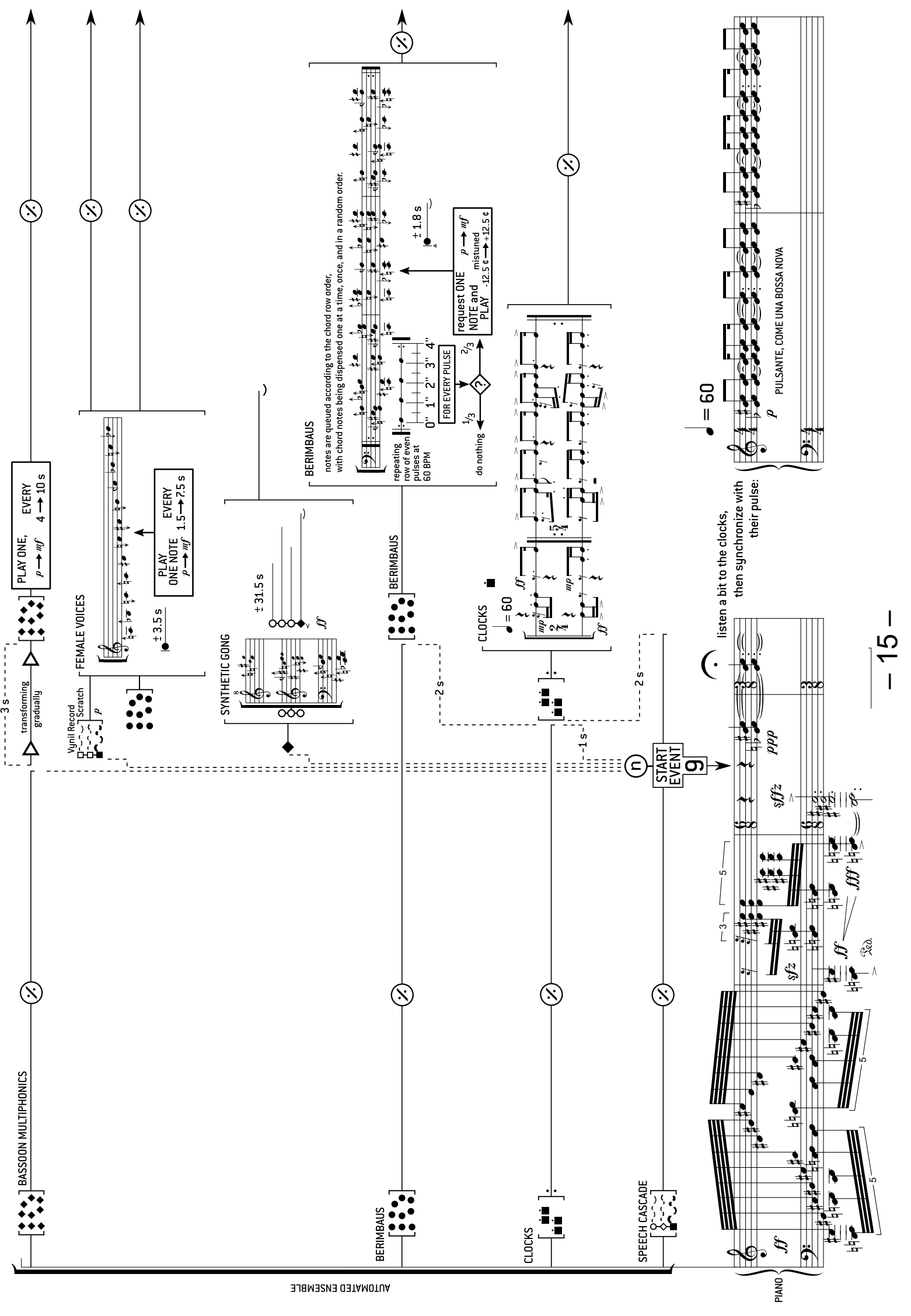

Source: (BITTENCOURT, 2020, p. 15) 
I trust these last two examples will be enough to give a good idea of the effort which was undertaken to give Malédiction a more proper, definitive and finalized score, one which - I say it happily and not without some sense of relief - I am now very much comfortable in giving to other pianists to play. Which brings us - voilá - to our last and twelfth directive: if one has understood well both the model-reader and the intertextual universe of one's composition, and one has acted accordingly in one's writing by making the appropriate choices and taking the proper actions, then there is no reason for not having faith in the ability of a reader to fruitfully resolve the rigidity of one's written signs.

\section{ACKNOWLEDGMENTS}

This research was conducted under the auspices of the Graduate Studies in Music Program of the State University of Maringá-PR, Brazil (Programa de Pós-Graduação em Música da Universidade

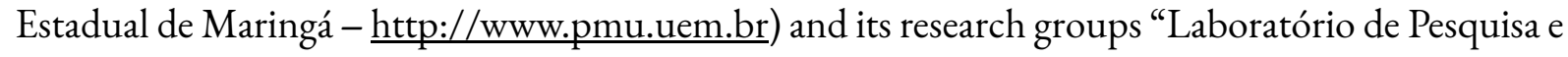
Produção Sonora - LAPPSO” (http://www.dmu.uem.br/lappso) and “Os Problemas da Interpretação".

\section{REFERENCES}

AROM, Simha. African Polyphony and Polyrbythm: Musical Structure and Methodology. Cambridge: Cambridge University Press, 1991.

AUBRY, Pierre. Trouveres et Troubadours. Paris: Felix Alcan, 1909.

AUSTIN, J. L.. How to Do Things with Words. Oxford: Clarendon Press, 1962.

BAILEY, Derek. Improvisation: Its Nature and Practice in Music. New York: Da Capo, 1992.

BARTHES, Roland. Image - Music - Text. London: Fontana Press, 1977.

BENT, Margaret. "Resfacta” and "Cantare Super Librum". Journal of the American Musicological Society, University of California Press, Vol. 36, No. 3 (Autumn, 1983), p. 371-391, 1983.

BITTENCOURT, Marcus Alessi (composer). Malédiction (1st ed.). New York: Vultur gryphus (author's editions), 2001. Musical score, for piano and automated live electronics.

BITTENCOURT, Marcus Alessi. Doctor Frankenstein, I Presume ... or The Art of Vivisection. 2003. Doctoral Dissertation (Doctor of Musical Arts). Graduate School of Arts and Sciences, Columbia University in the City of New York, New York, USA. 
BITTENCOURT, Marcus Alessi (composer). Malédiction (2nd revised ed.). Maringá: Vultur gryphus (author's editions), 2020. Musical score, for piano and automated live electronics.

BLACKING, John. Problems of Pitch, Pattern and Harmony in the Ocarina Music of the Venda. African Music, International Library of African Music, Vol. 2, No. 2, p. 15-23, 1959.

BLOOM, Harold. The Anxiety of Influence: a theory of poetry. New York: Oxford University Press, 1973.

BLOOM, Harold. The Necessity Of Misreading. The Georgia Review, University of Georgia, Vol. 29, No. 2 (Summer), p. 267-288, 1975.

BRĂILOIU, Constantin. "Le folklore musical”. In: Musica aeterna. Zurich: Metz, 1949, p. $277-$ 332.

BUSONI, Ferruccio. Sketch of a New Esthetic of Music. New York: G. Schirmer, 1911.

CARDEW, Cornelius. Towards an Ethic of Improvisation. In: “Treatise Handbook”, London: Edition Peters, 1971, pp. xvii-xx.

CHOPIN, Frédéric (composer). Quatre Mazurkas, Op.17(1st edition). Paris: Maurice Schlesinger, 1834.

DERRIDA, Jacques. "Signature Event Context". In: DERRIDA, Jacques. Margins of Philosophy. Chicago: The University of Chicago Press, 1982, p. 307-30.

ECO, Umberto. The Role of the Reader: Explorations in the Semiotics of Texts. Bloomington: Indiana University Press, 1979.

ECO, Umberto. The Open Work. Cambridge, Massachusetts: Harvard University Press, 1989.

ESTREICHER, Zygmunt. Une technique de transcription de la musique exotique (Expériences pratiques). In: Bibliothèques et Musées de la Ville de Neuchâtel (Rapport), 1956, Neuchatel, 1957, p. 67-92.

FERAND, Ernest T.. What Is "Res Facta"? Journal of the American Musicological Society, University of California Press, Vol. 10, No. 3 (Autumn), pp. 141-150, 1957.

HEDLEY, Arthur; BROWN, J. E.; TEMPERLEY, Nicholas; MICHALOWSKI, Kornel. "Fryderyk Chopin". In: SADIE, Stanley (editor). The New Grove Dictionary of Music and Musicians, 6th ed.. London: Macmillan Publishers Ltd., 1980, vol. 4, p. 292.

JAKOBSON, Roman. Language in Literature. Cambridge: Harvard University Press, 1987.

NETTL, Bruno. Theory and Method in Ethnomusicology. New York: Collier-Macmillan Publishers, 1964.

NETTL, Bruno. Thoughts on Improvisation: A Comparative Approach. The Musical Quarterly. Oxford: Oxford University Press, Vol. 60, No. 1 (January), pp. 1-19, 1974.

SCHAEFFER, Pierre. Treatise on Musical Objects: An Essay across Disciplines (translated by Christine North and John Dack). Oakland: University of California Press, 2017. 
THORESEN, Lasse; HEDMAN, A. "Spectromorphological analysis of sound objects: an adaptation of Pierre Schaeffer's typomorphology.” Organised Sound, v. 12, issue 02 (August): pp. 129$141,2007$.

ULBANERE, Alexandre. Willy Corrêa de Oliveira: por um ouvir materialista bistórico. 2005. Dissertation (Master's Degree). Universidade Estadual Paulista - UNESP, Instituto de Artes, São Paulo, Brazil.

ZIMMERMANN, Jens. Hermeneutics: A Very Short Introduction. Oxford: Oxford University Press, 2015.

\section{ABOUT THE AUTHOR}

Marcus Alessi Bittencourt (b. 1974) is an American-Brazilian composer, pianist and music theorist born in the United States of America. He holds master's and doctoral degrees in music composition from Columbia University in the City of New York, and a bachelor's degree in music from the University of São Paulo, Brazil. He is currently a professor of composition, music theory and computer music at the Universidade Estadual de Maringá (State University of Maringá), in Paraná, Brazil. ORCID: https://orcid.org/0000-0001-5108-1777. E-mail: mabittencourt@uem.br 